NORBERTO BOBBIO (1909-2004)

5

AND LAW: A CENTENNIAL

7

TRIBUTE

11 Teresa Chataway

It is easy to praise a philosopher. It is difficult to make clear, to oneself and to others, the nature and significance of his achievement.

Karl Popper ${ }^{1}$

Norberto Bobbio's Birth Centenary on 18 October 2009 was marked in Italy AU:1 with a series of academic seminars and cultural events. The International Congress held in Turin provided a range of reflective presentations on his figure and significant contribution to scholarship and Italian public life. ${ }^{2}$ Bobbio was Italy's foremost legal, political and moral philosopher of the 20th century. For over 60 years, through the breadth of his scholarship and public engagement, he exerted a far-reaching influence on both academics and ordinary people. He played a central role in developing the interconnection of law, politics and morals, and communicating that knowledge to all levels of Italian society and beyond.

Bobbio was conversant in English, French and German. His first book in English, The Philosophy of Decadentism: A Study in Existentialism, was published in 1948. During the subsequent three decades, several of his legal and political theory articles appeared in Anglo-American academic journals.

Studies in Law, Politics, and Society, Volume 55, 155-184

Copyright $($ C) 2011 by Emerald Group Publishing Limited

All rights of reproduction in any form reserved

ISSN: 1059-4337/doi:10.1108/S1059-4337(2011)0000055010 
1 Concurrently, other translations, including some law texts, were published in Latin America, Mexico and Spain. Not surprisingly, it was in these countries,

3 which had experienced despotic regimes, that his theories of liberty, equality, democracy and human rights were so well received. Perhaps, it was also due

5 to the conviction pervading his writings on those principles that encouraged the germination of those seeds even in such parched ground. Bobbio's

7 theoretical clarity and crystalline expression are well acknowledged, and they operated as vital conduits to promote the kind of free persuasion that is

9 essential for an effective democracy: he observes that 'democracy needs clarity as much as humans need air' (Bobbio, 1945, p. 159).

11 Bobbio's writings are underpinned by his eclectic understanding, which derives from his synthesis of a body of knowledge in legal, political and

13 moral philosophy. Significantly, it was from such a perspective that he engaged with different interlocutors during the difficult years under fascism

15 in Italy. As an engaged intellectual, Bobbio considered complex questions from a principled position, and beyond national boundaries, and these

17 attributes distinguished his approach.

Bobbio's intellectual trajectory and interdisciplinary body of writings

19 provide a broad spectrum of understanding, which also reveals developed international mind. This spans his cultural origins steeped in the Piedmontese

21 landscape, his synthesis of Continental scholarship and thorough assimilation of the English classics, and includes his reception of Anglo-American

23 influences that he found relevant to particular social and legal areas.

While pursuing a research and teaching career in law and, in the later

25 phase, in political philosophy and science, Bobbio's commitment and reflection converged on an overarching question. How could law and

27 politics be harnessed to improve democracy within states, and promote international democratization? He contends that liberalism and democracy

29 can work together to attain such a goal, because as the former provides the freedoms necessary for the proper exercise of power, the latter guarantees

31 the existence and persistence of fundamental liberties.

Bobbio's intellectual, ideological and moral development was influenced

33 by particular historical events in Italy, when due to certain flaws in its political and cultural tradition fascism prevailed. His personal experience

35 under a totalitarian regime shaped his political commitment and inspired his academic endeavour. Thus, his legal and political philosophy emerged from

37 the antifascist struggle for the re-establishment of Italian democracy, the regaining of liberty and political and social rights. Bobbio advocated

39 dialogic processes, non-violence and democratic compromise to secure peace within the state. He argues that those pactitious processes occurred in 
1 post-war Italy, and subsequently applies that reasoning in his theory of 'legal or institutional pacifism' (Chataway, 2001, p. 143). That conception of

3 legal pacifism emerges from an historical line of classical thought, and his synthesis of the texts of Hobbes, Kant and Kelsen. Bobbio interprets and

5 develops Hobbes' contractarianism in a Kantian sense, attributing to it a universalistic and cosmopolitical value. At the same time, he interprets Kant

7 from a Hobbesian viewpoint, assigning to Kantian federalism the meaning of a real project for overcoming state sovereignty and progressing

9 cosmopolitical democracy. Bobbio draws on Kant's jus cosmopoliticum (cosmopolitical law) to broaden his theory of internal democracy beyond

11 national boundaries, that is, cosmopolitical democracy. Theoretically, this goal is no longer considered utopian in that the philosophical and ethical

13 premises for cosmopolitical democracy have gained greater acceptance by many states and global civil society. Pragmatically, the international

15 community is realizing that the resolution of many global issues and the prevention of transnational harm to both humans and the environment can

17 only emerge from an integrated perspective of law, politics and ethics. Currently, in the light of the global financial crisis and natural and/or

19 technological disasters, these conditions are increasingly being recognized as the cosmopolitical reality.

21 His reliance on Kelsen includes the precision of his scientific approach, the primacy of international law and the superseding of the traditional

23 concept of sovereignty (Bobbio, 1963b, 1964, 1973, 1992; Kelsen, 1942, 1973).

\section{WRITINGS IN ENGLISH}

29 Bobbio's vast body of interdisciplinary writings remains largely locked in the Italian language. In the 'Short Annotated Bibliography' to Kelsen's

31 Introduction to the Problems of Legal Theory, it is stated: 'Although several volumes of Bobbio's political theory have recently appeared in English, very

33 little of his work in legal philosophy has been translated' (Kelsen, 1992, p. 146). Similarly, the influence upon him of his Italian contemporaries, and

35 engagement with other international philosophers and authors, such as Karl Popper, Carl Schmitt, Hans Kelsen, H.L.A. Hart and Alf Ross, is virtually unknown to Anglo-American theorists. ${ }^{3}$

Awareness of Bobbio's work in the Anglo-American context is mainly due

39 to the commitment of one publisher, Polity Press (Bobbio, 1987a; see also Bobbio, 1995a, 1996a, 2000, 2001, 2002). These writings cover Bobbio's 
1 academic endeavour in political and moral philosophy, and document his intellectual trajectory and personal experience under fascism. These translated

3 books perform an important task for the Anglo-American public by situating Bobbio's writings within the intellectual and political contexts of their

5 formulation. They provide an essential understanding for examining the premises of his theories, and hence facilitate reflection that leads to persuasion

7 and action. There are other publications in English (Bobbio, 1956; see also Bobbio, 1990a, 1996b, 1996c).

9 Some academic political journals such as the New Left Review, Telos, Theory and Society, Thesis Eleven, The Australian Journal of Politics and

11 History and Convivio have published book reviews, interviews with Bobbio and informed articles on many aspects of his political and moral philosophy.

13 Only a few of Bobbio's legal articles are available in English (Bobbio, 1959; see also Bobbio, 1969, 1988, 1996b, 1998 and Bobbio \& Zolo, 1998). Two

15 texts, one on Thomas Hobbes and the other on human rights (Bobbio, 1993a, 1996a), are being rediscovered by international law schools. However, when

17 comparing the number of English publications in law and politics with Bobbio's overall production, relatively few of his writings are accessible

19 to Anglo-American readers. His books are generally collections of essays written for particular occasions, or addressing contingent issues. They reveal

21 how passionate he was about ideas, and indefatigable in the way one imagines Hobbes, Locke and Kant were. Bobbio's earnest message is one of

23 commitment to liberty, equality, justice and non-violence, which he considers fundamental principles for a working democracy in a globalized world 25 (Bobbio, 1987a; see also Bobbio, 1987b, 1990a, 1990b, 1990c, 1995a, 1996d).

For Bobbio, the new challenges to be confronted by democracy require a

27 deeper reflection and wider collaboration, both within and between the social sciences and law. By expanding the range of knowledges and processes, we

29 can deal more effectively with such persistent issues as social justice, human rights and the re-emergence of racism in a global society.

31 Another aspect of Bobbio's involvement as an academic and public intellectual is illustrated by his commentaries, which over two decades from

331976 appeared regularly in the Italian daily La Stampa, and in other newspapers and journals (Bobbio, 1997). This significant production has

35 been collected in three volumes of concise articles, which analyse practical societal issues and explicate aspects of political philosophy, political science,

37 law and ethics (Bobbio, 1981, 1995c, 1997). They represent a remarkable conspectus of Bobbio's pedagogic contribution to the progressive education

39 of citizens and democratization of institutions. While the majority of these materials is in Italian, an increasing number of translations is gradually 
1 appearing on the Bobbio Web site, maintained by the Centro Studi Piero Gobetti in Turin. ${ }^{4}$ Since his death in 2004 , several reflective pieces have also 3 become available in English (Bellamy, Ferrajoli, Negri, \& Zolo, 2004; Davidson, 2004; Ferrari, 2004).

5 Bobbio read key Anglo-American texts of the immediate post-war period to the mid-1960s, and reviewed them for Italian journals, when Italian

7 democracy was striving to establish its institutions and processes against a Cold War mentality. To illustrate, in law he reviewed Josef L. Kunz's Latin-

9 American Philosophy of Law in the Twentieth Century, Jerome Frank's Law and the Modern Mind, E. N. Cahn's anthropocentric view of law and J. D.

11 Wild on Plato's natural law. Political texts reviewed included Hugh A. Bone, American Politics and the Party System; Richard Hofstadter, The American

13 Political Tradition and the Men Who Made It; S. J. Hemleben's Plan for World Peace; Robert J. Niess on Julien Benda; Stephan Körner on Kant and

15 Walter Lippmann's Public Philosophy. From a societal perspective, including philosophy, he reviewed Dunham Barrows' Man Against Myth, Charles

17 Morris' The Open Self, H. Stuart Hughes' Consciousness and Society. The Reorientation of European Social Thought (1890-1930), Binkley's Contem-

19 porary Ethical Theories and Khatchadourian's The Coherence Theory of Truth. He also wrote an obituary on John Dewey, and followed Hans

21 Kelsen's writings while he was at Harvard and Berkeley. This non-exhaustive list reveals Bobbio's eclectic interest in legal, political and moral philosophy

23 scholarship emerging in post-war United States, and other viewpoints to inform and refine his reasoning.

29 Norberto Bobbio was born in Turin on 18 October 1909, into a middle-class family originating in Rivalta Bormida, a small town in the Alessandria

31 province of Piedmont. He attended the well-regarded Massimo D'Azeglio high school, and the University of Turin, where he gained two degrees.

33 The first was in law in 1931 with a thesis on 'Legal Philosophy and Legal Science', supervised by the highly esteemed legal historian and scholar

35 Gioele Solari (1872-1952). It is worth noting that during this formative phase, Bobbio and many of his peers and close friends were involved in

37 the antifascist struggle, which in most cases led to their imprisonment. ${ }^{5}$ At that time, Italian academic culture was distinctly influenced by German

39 intellectual developments, and Bobbio maintained that interest for most of his life. In 1932, he travelled to Germany with his friends, Renato Treves 
1 and Ludovico Geymonat, each undertaking research in their specific fields. He spent some time in Heidelberg to improve his German, and had the

3 opportunity to meet Gustav Radbruch and Karl Jaspers. Bobbio and his friends then attended a summer course in German philosophy at the

5 University of Marburg. In 1933, he gained a degree in philosophy with a dissertation on 'Husserl and Phenomenology', supervised by Annibale

7 Pastore, another distinguished scholar. On a subsequent visit in 1937, he met Carl Schmitt at his home for discussions, and to his surprise was asked to

9 dine with the family. Subsequently, they corresponded and Schmitt sent him his book on Hobbes, which Bobbio reviewed for the Italian public (Bobbio,

11 1939). This was the beginning of Bobbio's lifelong interest in Hobbes, whose work influenced his approach to natural law and positivist tradition, his

13 perspective on individualism, contractarianism and the attainment of peace through the establishment of a common power, or a 'Third party super

15 partes' by which constraint on the use of reciprocal force is guaranteed. This notion of the Third party is another distinctive feature of Bobbio's

17 contribution to international democratization theory (Bobbio, 1989).

Bobbio's teaching phase in legal philosophy began in 1935. Over a period

19 of 13 years he taught at the Universities of Camerino in The Marches region, Siena in Tuscany and Padua in Veneto. He also completed a study on analogy

21 in legal logic, his first major contribution to the analysis of legal reasoning, which fulfilled the state requirement for a university career (Bobbio, 1938). In

23 1948, he returned to Turin where he taught within the Faculty of Jurisprudence until 1972. Following the 1968 students and workers' unrest

25 in Turin, and elsewhere in Europe, the 1970s were a difficult period in Italy. Bobbio became more involved in political debates, and engaged with student

27 groups to try and resolve the controversies. These circumstances in part motivated Bobbio to accept the Chair in Political Philosophy at Turin

29 University. He continued teaching until 1979 within the Faculty of Political Sciences, of which he was also Dean from 1972 to 1975. Simultaneously, his

31 dialogic engagement with the Left and the political class increased, as illustrated by his numerous articles in La Stampa. Overall, he established a

33 reputation as a meticulous teacher, innovative researcher and inspirational mentor, and was renowned for his intellectual clarity, evaluative objectivity

35 and personal humility. Over the following four decades, he held a range of positions that benefited from his eclectic knowledge and professional

37 commitment. He was the national member of the Accademia dei Lincei, and from 1960 also a member of the Accademia delle Scienze and then its 39 president from 1976 to 1979 . From 1965, he was the correspondent member of the British Academy. He became president of the Centro Studi 'Piero 
1 Gobetti', a member of the 'Luigi Einaudi' Foundation scientific committee and of the 'Paolo Farneti' Centro Studi di Scienza Politica. From 1935, he

3 was editor of the Rivista di filosofia; associate editor of the Rivista internazionale di filosofia del diritto and editor of Comprendre, the journal

5 of the European Society of Culture. In August 1953, he was invited by Chaim Perelman to participate in the International Congress on legal logic held in

7 Brussels. Thereafter, he made regular contributions to other international meetings, and in 1957 met Kelsen in Paris.

9 Bobbio's unpretentious attitude and sense of privacy were acknowledged as personal attributes. He shunned public recognition, although this was

11 sometimes beyond his control (Bobbio, 1990d, 1996b, 2004). He was awarded various honorary degrees and international prizes during his

13 lifetime. Upon his death in January 2004 there was an extraordinary outpouring of grief and affection for him by individuals at all levels of civil

15 society. That would have amazed him. These events generated such a strong interest in his work that a series of public lectures by prominent scholars and

17 aimed at ordinary citizens was held in capacity venues over the subsequent months (Bobbio, 2006). ${ }^{6}$ Similarly, the Centenary programme was

19 organized to facilitate a broad participation by the academy, the general public and government officials.

\section{LEGAL SCHOLAR}

25 What is at the basis of Bobbio's legal philosophy that prompted him to define law in a particular way? How does he explain the relationship

27 between law, power and the state? The excerpts below provide an insight into the development of a number of Bobbio's theories, and reveal aspects of

29 his contribution to legal philosophy and jurisprudence. The first citation is found in an analytical tribute following his death:

One cannot underestimate Bobbio's importance for generating the impetus in Italian analytical legal positivism, and the general theory of law in the Italian tradition. His support for legal positivism, or what opponents may term legal formalism, means upholding the procedures of the rule of law underpinned by a critique of natural law. In particular, in the immediate post-war there were the attempts to attribute Hitler's horrendous acts to legal positivism. What he criticizes (Bobbio, 1965a) is not the need to judge law morally and politically, but the claim of being able to do this on the basis of objectively valid principles, as if moral judgements can be arranged into a detailed and articulated natural law based only on universal reason. For Bobbio, however, this claim rests on the illusion arising from moral principles which are formulated so vaguely as to conceal radical moral divergences. Whereas the type of positivism accepted by Bobbio 
1 maintains the separation between law and morals, and offers the possibility to describe positive law without reference to morals. Therefore, law is what it is even when that is morally unacceptable. In other words, because an act is prescribed by positive law does not mean that it is just. Thus the charge levelled at legal positivism that it allowed acquiescence to Hitler's monstrous acts is based on the confusion between the two types of legal positivism, which are mutually incompatible. Ideological legal positivism for which everything that is law is just, and the legal positivism advocated by Bobbio, which describes law as it is; or a scientific description of law and, if necessary, to criticize it. Law is the domain of political choices translated into words that express legal norms. These are themselves products and can produce other norms. They constitute the large apparatus of the legal system, as outlined in Hans Kelsen's legal theory and by which Bobbio is largely inspired (Bobbio, 1992). Moreover, something that does not escape

11 Bobbio's attention is that the normativist theory of law is functional in modern law and its determining features: from the democratic method to the separation of powers. Thus the legislator's ethical and political choices must be embodied in general norms expressed through intersubjective language. (Jori, 2004)

15 Another pertinent citation appears in Bobbio's 'Opening Address' at the 17th IVR World Congress in Bologna. By tracing legal philosophy over

1760 years, he observed that the gap between Continental and AngloAmerican theories had been bridged. He acknowledged that legal positivism

19 as a theory 'continues to be a valid approach to the study of law ... that is, law as it is and law as it ought to be, and by the conviction that the law

21 which lawyers most often deal with is of the former variety' (Bobbio, 1996b, p. 123). He noted that legal positivism as an ideology had been abandoned,

23 and in the following explanation he provides his synthesis of law and politics:

Circumventing the gulf between natural law and positive law is largely the result of the fact that today more so than in the past, we live and work in a universe of shared values, which are those of liberal democracy construed as a set of rules for living together. These rules are based on the acknowledgment of human rights and aimed at eliminating the use of force as a solution to social conflict. An outright confrontation, like that experienced by my generation, between Kelsen's democratic normativism and Schmitt's authoritarian decisionism would be impossible today and even now appears anachronistic. Yet the skies of our shared ideals are not crystal clear and I see dark clouds looming on the horizon. (ibid.)

In his 'a universe of shared values', Bobbio acknowledges value pluralism

35 in legal and political theory. The above prescient final sentence was stated more than half a decade after the 1989 failure of historical communism

37 and half a decade before 9/11. That failure left one remaining superpower. In the subsequent two decades, there were local wars and 'sword power'

39 expressions in different places and contexts around the globe. The so-termed war against terrorism continues unabated. Hegemonic large states (United 
1 States, China and India) act to maintain their status on the world stage, and there are mixed reactions, both internal and external, to the European

3 Union's more assertive stance. The changing substance of citizenship in a multi-level world is causing pressure at the borders and internally in many 5 countries (Chataway, forthcoming).

The third excerpt is drawn from an essay of the mid-1960s, where Bobbio 7 addresses the nexus between war and law through four different and seemingly contrasting relations: war as the antithesis of law, war as a means

9 to effect law, war as an object of law and war as a source of law. He uses the following metaphorical depiction of the function of law:

The function of law can be compared with the embankment and channels of a river. A legal system represents the embankment and channels of powers within a social group. From the large dam, or the Constitution, which forms the collector basin, one moves on to the quotidian and specific work of the farmer, who opens the furrows to water his field and then closes them with small mounds of earth. In other words, one approaches the specific rules that open or close a system. As far as different individuals are concerned, there are prohibitive rules to prevent the flow of power, or permissive rules to permit the flow of power. To date, no legal system has managed to become a perfect embankment and channels system. This is because the water sometimes disperses into rivulets outside the irrigation plan, and thus the water finds its own direction. Those rivulets can be regarded as residual powers. At other times, it can happen that either the embankment or the large dam collapses, and such a moment in legal terms is described as a state of extraordinary powers [or exception]. (Bobbio, 1965b, p. 333)

23 The fourth citation is a comment in the proceedings of the 1960 Bellagio Conference on Legal Positivism. It reveals Bobbio's method of elaborating an argument through historical and social-scientific theory:

On another occasion, there had been almost two hours of discussion about the notion of formalism in connection with legal positivism. It had been proposed in a paper by Professor Shuman that it was misleading, if not mistaken, to describe Kelsen's theory as formal. At this point Professor Bobbio suggested there definitely was one sense in which Kelsen was a formalist: namely, that he, Kelsen, attempted to define law by reference to its form and not to content, and that this was a well-established distinction. Professor Hart then raised the objection that he did not believe there was, at least in this context, a significant difference between form and content, and at minimum, Professor Bobbio should make it plain how he distinguished between form and content. Professor Bobbio replied by reading a passage from Kant's The Critique of Practical Reason in which the distinction was used. We should like to observe that Professor Bobbio's impulse was to satisfy Professor Hart with an historical example instead of an analytical explanation. Such a mode of response, we contend, would be rare, indeed, in the Anglo-American tradition. $^{7}$ (Falk \& Shuman, 1962, p. 216, original emphasis)

39 These citations illustrate some fundamental aspects of Bobbio's legal philosophy. They reveal his engagement with natural law and legal 
1 positivism, his concern with the distinction between law and morals and his continuing interest in the function of law in society. They highlight his

3 historical approach interwoven with analytical philosophy, as applied to the general theory of both law and politics (Bobbio, 1993b). Another significant

5 feature is Kelsen's influence on his legal and democratic thought. That intellectual engagement provides critical linkages between law and power in

7 a democratic state, peace through law and legal (or institutional) pacificism. Bobbio's reflection over time, however, leads to certain departures from the

9 Kelsenian premise of the legal system in that by drawing on legal sociology he formulates an argument for the promotional action of the state.

11 Accordingly, Bobbio's intellectual development traverses both law and politics, and this combination is crucial to his theorization of formal and

13 substantive democracy, which, he asserts, became the 'magnet for a lifetime of research' (Bobbio, 1996d). Throughout that search he pursued a workable

15 synthesis of the liberal concern for individual liberty, the rule of law and the protection of human rights with the socialist concern for equality, social

17 justice and peace. He expresses that aim as follows:

19 I trust I will not appear presumptuous when I say that having cultivated both legal and political studies allowed me to consider the many complex issues of human coexistence from two points of view, which complement each other... . [O]n the one side, there is the

21 perspective of the rules, or norms as jurists prefer to call them, whose observance is essential for a well ordered society to exist. On the other, there is the perspective of the equally necessary powers, which allow rules or norms to be prescribed and, once they are, to be obeyed. Legal philosophy is concerned with the former and political philosophy with the latter. Law and power are two sides of the same coin. A well ordered society needs both. (Bobbio, 2001, p. 86 [trs. modified])

27 For Bobbio, such an ordered society is realized through representative democracy and becomes operational according to a set of rules ('rules of the game'). As with the legal system, to avoid the risk of authoritarian or despotic regimes such rules must be upheld in a democratic system.

31 He distinguishes between the legal philosophy of jurists and the legal philosophy of philosophers. He favours the former and considers it is the

33 task of legal philosophers to work with jurists, and thus engage in a mutually meaningful conversation (Bobbio, 1965a). In his 1970s writings he maintains

35 that legal science has a dual task: not only to know legal rules but also to innovate and/or create them. When discussing legal science he specifies its

37 relationship with the social sciences, and extends one of his earlier themes in that 'today more than ever, the progress of studies in the general theory of

39 law depends on the use a legal theorist can make of those instruments provided by the social sciences' (Bobbio, 1974, p. 9). With regard to the 
1 connection between jurists and sociologists, he maintains that they 'practise two different tasks'. While jurists use rules 'to qualify behaviour as lawful or

3 unlawful', sociologists use rules 'to explain why individuals behave as they do’ (Bobbio, 1977, pp. 25, 55).

5 That 1977 volume includes essays on the promotional function of law, positive sanctions, dichotomies in legal theory and structure and function in

7 Kelsen's legal theory. Bobbio's analysis of the function of law provided him with an opportunity to compare both Hart and Kelsen on the structure and

9 function of law. After acknowledging the practical and political purpose of Kelsen's legal positivism, Bobbio reasserts his reliance on the general theory

11 of law. He regarded it then, and subsequently, as a discipline that can provide 'useful conceptual instruments for understanding both enduring

13 and changing law, law of the past and law of the future' (Bobbio, 1970, p. 9).

One of Bobbio's research outcomes was a new approach to legal theory

15 aimed at finding a cognitively appropriate representation of law. He moves on from the distinction between description and prescription of the 1960s to

17 highlight the ideological character of Kelsen's normative theory. During the 1970s, his frame consisted of a legal theory, which from a functional

19 perspective considered law as a system dependent on the overall social system (Bobbio, 1963a; see also Bobbio, 1968, 1970, 1971, 1974, 1975,

21 1984a, 1987c). He maintained that a formal, or structural, theory of law could not represent adequately the legal reality prevailing in contemporary

23 industrial societies. Hence, a general theory of law that addressed the question of function by recognizing the promotional, as well as the

25 protective-repressive, function of law was an approach that would provide a more adequate representation of law. He explains, however, that functional

27 theory does not affect the validity of structural theory, but what is required is the integration and parallel development of both. A logical flow-on was

29 that he allowed that approach to interpenetrate his legal theory. His writings during the 1980s attest this critical shift.

31 In Bobbio's legal writings, it is therefore possible to identify at least three significant aspects of his contribution to contemporary legal theory and

33 jurisprudence. The first reveals that he was one of the major promoters of the neo-positivist and linguistic-analytical approach to law in Italy. The

35 second demonstrates his understanding of the contributions made by Hans Kelsen, Alf Ross, Karl Olivecrona and H.L.A. Hart to normative-analytical

37 approaches to law. In terms of his legal theory and the general theory of law, he considered those authors' influence in varying degrees. The third aspect

39 consists of his critical and developmental analysis of the promotional function of law, ${ }^{8}$ at a time when the state was evolving from a police state to 
1 a Welfare State. As a result, he changed his analytical perspective from the structural to the functional (Bobbio, 1977). After reaching this elaboration

3 Bobbio accepted the Chair in Political Philosophy, and this was a turning point in his focused legal endeavour. Notwithstanding, in the later phase of

5 his career he incorporated much of his legal thought into the development of his political philosophy generally, and democratic theory in particular.

\section{JURISPRUDENCE AS LINGUISTIC ANALYSIS}

11 In March 1949, Bobbio presented a paper on 'Legal science and linguistic analysis' at a conference held at the Centre for Methodological Studies

13 in Turin (Bobbio, 1950). This Centre, of which he was a co-founder, was an important venue for the promotion of interdisciplinary discourse and

15 research among intellectuals and practitioners. Its objective was also to stimulate greater interest in applying scientific analysis to law.

17 Bobbio aimed to draw the attention of jurists, and other theorists engaged in scientific research in general, to the contribution of the new conception of

19 science. He argued that the use of recent methodological perspectives could provide jurists with a better understanding of their research process, and this

21 would lead to a new, or more appropriate, approach to legal science. This could be achieved through the neo-positivist conception, which includes the

23 understanding of the research undertaken by jurists in the ambit of the sciences. It would also help jurists to comprehend the nature of their activity

25 as researchers who seek to formulate a coherent system of assumptions. This, he asserted, is jurisprudence, or that general and specific theory of a

27 particular positive law. He contended that jurisprudence could fit quite well with those perspectives.

29 There are six key aspects to the paper. First, Bobbio states that, according to the types gradually formulated by the different theories of science, up to

311950 jurisprudence did not qualify as a science. The conceptions advanced by knowledge and science were such that jurists had failed to have their

33 investigations included among them. Bobbio remarks that with respect to other scientists, perhaps jurists suffered from a kind of 'inferiority complex'.

35 Second, he identified that, on one hand, there was a type of jurisprudence that was not science, and on the other there was a science which in itself

37 had nothing to do with jurisprudence. This contrast between science and jurisprudence, instead of rendering jurisprudence into a science, could lead

39 to the construction of a legal science distinct from jurisprudence. Third, according to the rationalist conception of science, natural law was the "true 
1 legal science', or the definitive knowledge of human laws that, due to the object's very nature, could not possibly be established by jurisprudence.

3 Because the rationalist conception could not reduce the jurists' research into its schema, it produced a type of legal research that differed from

5 jurisprudence. As a result, the sphere of legal knowledge was divided into two. One consisted of a new knowledge asserting that to be 'true' did not

7 necessarily mean it was not 'legal' (natural law). The other was the traditional knowledge, which by asserting that it was 'legal' did not mean

9 that it was not 'true' (jurisprudence). Fourth, according to the positivist conception of science, the only legal sciences possible were sociology and

11 legal psychology. Since for the rationalist conception, natural law was the only legal science possible, neither of the two conceptions was jurisprudence.

13 Thus, it continued on its path as it could not do otherwise.

Moreover, Bobbio explains that when jurisprudence was compared to

15 natural law, it was regarded as a simple technique or an art, and when it was compared to empirical science of legal facts, it was considered dogmatic.

17 Thus, jurists trying to unravel the problem of legal science found themselves having to deal either with a science that was not jurisprudence or with a type

19 of jurisprudence that was not science. Fifth, after considering the position of legal science which was discarding obsolete principles and arbitrariness, as

21 proposed by Julius Kirchmann, ${ }^{9}$ Bobbio re-presented the question. He asked whether, in light of the prevailing contrast between jurisprudence and

23 science, and as jurisprudence did not fall within the canon of the true conception of science, might jurisprudence be a false science. Or, whether the

25 conception of science was a false conception because, among other things, it was unable to account for jurisprudence. Sixth, Bobbio contextualized his

27 paper within the emergence of the modern conception of science. According to this, the greater or lesser scientific characterization of research derived

29 from the degree of rigour of the language used. Any observation that was not expressed through a scientific assumption, that is, an assumption that

31 fulfilled the criteria of scientific language, had neither the value nor the characteristic of a scientific observation.

33 Based on these six general premises, Bobbio then asked: Can jurisprudence be located, and if so how, within this new way of understanding

35 science? He proceeds by first establishing that the subject of concern to jurists is a system of 'rules of behaviour'. Confronted with such rules, which

37 constitute the subject of the jurists' investigation, the aim of jurisprudence is to undertake two distinct but connected types of research. These are either

39 to analyse the 'rule' for itself or the content of the rule, that is, what is being regulated. The study of the rule is the concern of the general theory of law, 
1 which Bobbio contends could be more appropriately termed formal theory of law. The study of the content of the rule, or legal norm, constitutes

3 jurisprudence. The importance of normative theory now becomes clear. In order to delimit the object of jurisprudence, jurists must exclude from their

5 field of research all ethical-political inspirations. These constitute principally the content of natural law (the search for the ideal foundation of a

7 norm), whereas the investigation of facts concerns the content of sociology (the search for the true origin of a rule). For Bobbio, these were the main

9 paths that led to the non-recognition of jurisprudence as a science.

Bobbio then addresses jurisprudence as linguistic analysis. As stated above,

11 the object of jurisprudence consists of normative assumptions, and these in turn are themselves the outcome of previous empirical investigation.

13 Jurisprudence consists exclusively of the critical dimension inherent in any scientific system. In other words, it is the construction of a rigorous language

15 that aims to communicate effectively previously established experiences. Thus, Bobbio considers that linguistic analysis is the critical dimension

17 common and indispensable to every type of science. Jurisprudence, then, in its essential dimension is linguistic analysis. It is the analysis of that specific

19 language in which legislators express normative assumptions. Linguistic analysis operates in the legislative discourse in the same way as any other

21 science that is confronted in the physical or mathematical discourses. This kind of analysis must transform a legislative debate into a rigorous discussion,

23 and it is only on this basis that it becomes a science. This rigorous discussion represents the complex activity that traditionally has been regarded as that

25 undertaken by jurists. This is the interpretation of law that employs the appropriate language to express legal rules. Thus, if legal linguistic analysis

27 and legal interpretation are one and the same, and if linguistic analysis is the inherently scientific activity of jurists, it must be concluded that jurists, as

29 interpreters of laws, produce legal science. Rigour therefore is the essential characteristic of any research that claims to have scientific validity.

31 Finally, Bobbio outlines three phases in the development of jurisprudence. These pertain to jurisprudence when it is understood as linguistic

33 analysis whose object consists of the normative assumptions of a particular legal system. (a) The first phase concerns purification - as the language of the

35 legislator is not necessarily rigorous, the first task of the jurist is to render it more rigorous; (b) The second phase relates to completion - as the language

37 of the legislator is not necessarily complete, the second task of the jurist is to complete it as much as possible; (c) In the third phase legal language is 39 organized into a system - as the language of the legislator is not necessarily ordered, the third task of the jurist is to systematize it. A jurist's research 
1 activity, in the traditional sense of the term, is conducted and concluded through the cycle of these three phases. This is the case, at least, in legal

3 systems that are based principally on the production of law by legislation. Thus, the activity of legislators and that of judges is quite distinct. Similarly,

5 the activity of the jurist who interprets laws differs from that of the judge who applies them.

7 The following is a brief description of Bobbio's analysis of the process that occurs in each of the three phases. In the first phase, purification of the

9 language is achieved according to the rules governing the use of words, or the grammar of legislative language. By saying that a legislator's language

11 is not necessarily rigorous does not mean that the language lacks meaning, or is ambiguous or vague, in the way common language might be. The

13 legislator uses a language that was defined and constructed by jurists during the course of a long tradition. Jurists usually begin their analysis with the

15 definition of the meaning of the words that fall within a normative assumption, or within the group of normative assumptions which constitute

17 the object of their research. This analysis aims to establish the system of rules that determines the use of a particular word. This system of rules in

19 turn constitutes the concept corresponding to that word, for example, property or mandate.

21 In the second phase, Bobbio explains that insufficient rigour is a warning that the language of the legislator is also incomplete. The flaw of incompletion

23 is understood in the sense that an assumption that is not expressed through rigorous language is an assumption devoid of all the rules regulating the use

25 of the words that constitute it. Such incompletion, however, is compensated by a grammatical analysis of the language. The incompletion considered here

27 refers to the use of that expression in the legal tradition. Thus, it indicates the fact that the legislator does not draw all the possible normative consequences

29 from the expressed normative assumptions. These are derived from the simple combination of assumptions, which according to the rules of

31 transformation are accepted as legitimate. Accordingly, the second phase of a jurist's investigation aims to establish that (a) the language of the

33 legislator is, in this specific sense of incompletion, incomplete; (b) like any language, as the legislator's language is gradually rendered more rigorous, it

35 becomes complete.

The third phase is the systematization. As stated, legal language is neither

37 necessarily rigorous nor complete. Furthermore, it is not necessarily ordered. According to Bobbio, the normative assumptions that constitute a legal

39 system are the result of diverse and distant historical stratifications. These emerged from their mutual superimposition at different times, and their 
1 placement alongside each other occurred without any general plan for their order. Where a plan gradually emerged it was possibly too historically

3 laden to be able to satisfy the systematization requirement, as this is only concerned with the logical aspect.

5 Bobbio contends that in the field of law, the progress of legal science depends on the preparedness of jurists to undertake a systematic elaboration

7 of law that makes no concessions to tradition simply because it is a tradition. Moreover, when considering the plurality of meanings of words according to

9 different contexts, or in the language systems they are inserted, jurists should only be guided by the rules of the language being examined. Such a rigorous

11 process will enable them to elaborate a coherent and unitary language which, as much as possible, will eliminate margins of incomprehension. This is also

13 an additional advantage for the practical application of law. It is evident that the normative system considered by jurists is not perfect (the issue of the

15 lacunae), as quite often a deduction opens the way to two contradictory solutions (the issue of the antinomies). These two issues as well as that of

17 analogy, however, due to space limitation, are not discussed.

Given the paradigmatic nature of his argument, Bobbio provides the

19 following synthesis:

21 The history of natural law is the history of a great evasion. The history of jurisprudence began when this evasion ended. Jurists coming into their own realized that what they were seeking to do outside their walls could be accomplished by remaining within them. And even within these walls, due to the extended neglect, there was a great deal, in fact almost everything, still to be done. The rigour they employed in formulating the ideal law could have been better used to design the system of the law in force. This is the task that will enable jurists to be more directly and immediately useful to the process of social construction, in respect of which they are required to apply their legal analysis. (Bobbio, 1950, p. 367)

\section{SOCIOLOGICAL THEORY AND THE GENERAL THEORY OF LAW}

Bobbio discusses legal sociology in its relations with the general theory

35 of law, and traces the shift from structure to function in his 1975-1984 writings (Bobbio, 1974, 1975, 1984a). According to Bobbio, legal sociology

37 encompasses a whole range of theories and approaches, which in one way or another connect law to society. Thus, law is not regarded as a phenomenon

39 for itself, but as one of the social phenomena. In other words, the legal system is not analysed independently but as a sub-system within the broader 
1 and more complex social system. He argues that instead of talking about a 'conception of sociology of law' that 'attributes the task of distinguishing 3 law from other elements of social life to this discipline', one should talk about sociological theories of law. It is this 'sociological' aspect that 5 distinguishes those theories from other legal theories of law. Accordingly, what is the sociological aspect that enables their recognition? For Bobbio,

7 the answer lies in both the subject and the approach of legal sociology. Sociologists who specialize in these areas tend to formulate general theories

9 of law that take into account certain aspects that connect law to society as a whole, rather than those aspects that separate law from society. Hence, their

11 results can quite rightly be considered sociological theories of law.

In retrospect, if one considers the history of the general theory of law over

13 the past century, at least since Jhering, ${ }^{10}$ it reveals a continuous opposition between sociological and non-sociological theories of law. Although socio-

15 logical theories of law were nevertheless general theories of law, they were not so discernible because essentially these were conceived by jurists (from Austin

17 to Kelsen), rather than by sociologists. According to Bobbio, the term 'general theory of law', at least in the Continental tradition of legal science, was always

19 'non'-sociological. This became quite evident in its most elaborated and now classical form, such as the Kelsenian, in which the general theory of law

21 excludes explicitly any connection with sociology. Moreover, compared with any other possible theory of law, such exclusion becomes the fundamental

23 reason for its superiority. Bobbio observes this linguistic use is so grounded that some years ago, after analysing the major and more recent 'general

25 theories', including Kelsen's, he discovered what they held in common and justified the same denomination was that they were 'formal' theories of law.

27 These theories analysed law rigorously and established the 'forms' of any possible legal experience, but at the same time they rejected any forays into

29 fields usually reserved for sociology. Those forms consist of the fundamental concepts, such as rule and system, law and duty, obligation and responsibility

31 and violation and sanction, which are present or presumed in any legal system (positive and non-positive).

33 Bobbio also remarks that when the 'general theory of law' was introduced in the Italian education system as a new discipline, it was understood in the

35 sense that prevails from Augustus Thon to Hans Kelsen, that is, as a formal theory of law. However, it is clear that the term (and linguistic use) is one

37 thing, the concept another. Besides the prevailing linguistic use, a 'general theory of law' indicates a representative and explanatory theory of law. It

39 conveys the same meaning of 'general theory' as that used for 'language', 'the state' or 'the economy'. Thus, there can be different general theories of 
1 law, according to the different perspectives being considered. Historically, the alternation has been between two perspectives: the formal viewpoint

3 which reflects the hegemony of Kelsen's work and is termed 'pure', and the other viewpoint which is the sociological.

5 Bobbio maintains that identification of the difference between a nonsociological and a sociological theory of law rests in its specification. Non-

7 sociological theories of law, which also fall within the term of general theories of law, are those theories that focus their analysis and re-construction on the

9 'structure' of the legal system, whereas sociological theories are those that primarily consider the function of the legal system. He underscores this

11 distinction between structure and function because, in his view, that better than any other distinction allows one to identify the two different ways in

13 which the general theory of law operates. Moreover, such distinction can be used to highlight what characterizes the sociological approach, and thus

15 justifies its importance. Undoubtedly, non-sociological or 'formal' theories of law are more concerned with knowing 'how law is constructed' than 'what

17 is its use'. This is because formal theories identify the distinctive character of law by the way the legal system is structured, rather than the aims it seeks to

19 achieve.

Bobbio considers that the most conspicuous examples among the legal

21 theories that sprouted from the 'stump' of general theory are those by Kelsen and Hart. For Kelsen, the characteristic of law is a dynamic normative system,

23 in contrast to static normative systems. For Hart, the characteristic of law is that law is a normative system consisting of primary and secondary

25 rules (Hart, 1961; Kramer, Grant, Colburn, \& Hatzistavrou, 2008). Both characteristics are structural and do not indicate what the aim of law might be.

27 They only inform us that the legal system has a certain structure, and this distinguishes it from other normative systems.

29 However, Bobbio suggests that if one is interested in understanding the function of law in society, they should turn to functionally oriented studies,

31 such as those undertaken in cultural anthropology. For example, he acknowledges Krader's anthropological perspective in his Anthropology and Early

33 Law where he observes that 'the historical study of the law opposes the idea that the law is a self-contained system which proceeds analytically - that is, by

35 perfecting its own internal devices - and independently of the society around it... . Society as an internal factor influencing the development of the law has

37 since then entered another way' (Krader, 1966, pp. 4, 16).

These studies are included in the area of research that investigates global

39 society and law as part of the social system. In short, one must turn to sociology. Traditionally, the general theory of law rests on a definition of 
1 law that reconstructs its technique of sanction and highlights the specific form of sanction attainable through coercion (thus defining law as a coercive

3 system). It follows that the general theory of law is described by its internal functioning, whereas sociological theories recognize its specific form of

5 social control. In other words, sociological theories characterize law as a function of the service it renders society. While stating that law is a coercive

7 system tends to convey how law operates, by saying that it is a form of social control reveals immediately the aim of law, or its direction. Bobbio notes

9 that Marx and Engels and even Parsons ${ }^{11}$ considered law from a global view of society. This means that it is a sociological rather than a formal theory of

11 law. In such a vision, the position of law is principally determined by the function it expresses, and only subsequently, and marginally, by its internal

13 structure.

By the mid-1970s the debate over the function of law had gained

15 momentum, as demonstrated by the fact that it was the main subject at the World Congress on legal philosophy. ${ }^{12}$ Hence, the predominant struc-

17 turalist conception of law was increasingly being replaced by a functionalist conception. This shift was considerably influenced by the tendency to

19 consider law from a sociological perspective, or within the framework of a renewed expansion in studies of legal sociology. However, as Bobbio

21 observes, such revival was not accidental, but was produced by the significant social transformation of the traditional conception of the state

23 under the rule of law. In such a state, whose apparatus consisted solely of the protective-repressive function, this role was endorsed unanimously, and

25 for this reason it went unquestioned.

For a long time, the analysis of the depiction of law was concerned with

27 a general theory based on the fundamental concept of law as a coercive system. This was, in turn, a reflection of the conception of the modern state

29 as a system of monopolized force, which extends from Hobbes to Weber. While consideration on the function of law abated, the general theory that

31 addressed the structural study of law advanced through more refined logical and analytical instruments. This is illustrated by two important works by

33 Hohfeld (1913-1914), which addressed the theory of active and passive relations and the theory of law as a legal system. This system consists of a set

35 of normative propositions concerned with investigating three characteristics: unity, coherence and completeness. Such a conception extends from Kelsen

37 to the work of $\operatorname{Raz}(1976,1990)$ and Alchourrón-Bulygin and Bulygin (1981).

Bobbio further contends that the gradual configuration of the modern 39 state as a complex organization prompted the analysis of the structure of law. This is the process of legal regulation of state power at all levels of 
1 government right up to the highest, which are subject to constitutional rules. That process was effectively described by Weber as the rationalization of

3 power. Theoretically, both the theory by degrees in Kelsen's legal system and Hart's theory of law as a complex of primary and secondary rules

5 resulted from the development of the modern state into a large organization. At that historical juncture, the state was considered the largest entity in

7 societies that also domiciled several large organizations; today's multinationals. But transformation of the state into a large organization was in

9 part the consequence of the multiple tasks, which were gradually attributed to it in an industrialized society. It was therefore inevitable that the change

11 in the state's tasks should direct the attention of jurists to the transformations of law, to use Duguit's term. ${ }^{13}$ This transformative process generated

13 increased awareness in those theorists who were no longer prepared to consider the study of law as an independent system, but perceived it as

15 dependent on the global social system. Bobbio was receptive to this new awareness. He considered that the traditional theory of law was lacking on

17 the question of the function of law, and there was a need to extend the analysis of law in this direction.

19 Given the importance Bobbio placed on the 'promotional function' of law in the modern state, in particular with the emergence of the Welfare State,

21 he contended that this new feature of law could not be resolved without the help of sociology, both as a general theory of society (in this case of

23 industrial society, which created the phenomenon of promotional law), and as empirical and behavioural research. He concluded that the progress in

25 the general theory of law would depend more than ever on the ability and preparedness of legal theorists to use instruments provided to them by the 27 social sciences.

Bobbio's contention that the general theory of law required further

29 development led to his formulation of a 'promotional function of law', which exhibited the following features:

- open perspectives towards natural law and legal positivism;

- the interconnection between the specific nature of legal sanction and sanction as the differentiating element of law in a legal system;

- the place for primary and secondary rules in a legal system and as functions of a liberal democratic state; and

- the process of de-ideologizing the study of law.

Their considered combination provides an understanding of law as a

39 system dependent on the overall social system. The promotional function represents an iterative development in Bobbio's reflection on legal history 
1 and legal philosophy, and denotes the importance he accords to the distinction between law as fact and law as value. Law as it is and law as

3 it ought to be. It is evident that by the mid to late 1970s, Bobbio's conceptualization of a 'promotional function of law' reflected law as it ought

5 to be, since it incorporated the increasing linkage of the general theory of law with the social sciences. Therefore, it is neither natural law versus legal

7 positivism nor is a monist position on the general theory of law tenable. Rather, Bobbio's notion of a dualist perspective, which he developed along

9 the lines of a promotional function of law, provided novel insights into the nexus of law and politics. These have become more evident in the complexity

11 of late modernity and its attendant need for theory with practical values.

What then is the meaning of 'legal-political'? First, Bobbio contends that

13 there is no avoiding the essential relation between law and politics. Law must be amended and updated by politics and politics must be regulated by law.

15 This entails recognition of the interdependence of legal and political theory when addressing specific issues. The dialectic between law and politics is

17 constantly operative in his writings. For him, to set law up against politics, or politics against law, is an abortive exercise. Such a definitional tussle

19 has little validity. What may have been non-political a century ago is eminently political today. No controversy or issue is intrinsically political

21 or intrinsically legal. A refusal to acknowledge political and social factors cannot keep law neutral, for even such a refusal is not without political and

23 social ramifications. In his investigations of legal and social phenomena, Bobbio aimed to discover how desirable social goals may best be achieved.

25 His legal-political reasoning continually addressed the interconnection between rights, democracy and peace, and the progressive democratization

27 of states within the international community. In that context, as a neoKantian, Bobbio contends that, like Kelsen, peace as a legal postulate cannot

29 be attained without implementing Kant's cosmopolitical law. Recognition that human rights must be protected beyond individual states demonstrates

31 that 'we are moving towards an international law whose subjects are no longer just states, but also, and especially, individuals' (Bobbio \& Zolo, 1998,

33 p. 367). Bobbio's developed via media reveals a significant utility when considering contemporary issues, which are influenced by international law

35 and global politics.

Here, a distinct difference between Bobbio and Kelsen on the legal-political

37 nexus is noted. In Kelsen's view: 'If [the writer] tries to make his readers believe that his policy is in conformity with international law interpreted

39 "politically", he does not present a scientific theory of international law but a political ideology' (Kelsen, 1952, first edition p. viii, second edition p. ix). 
1 Kelsen, however, shifted his position. In his earlier writings, he stressed the dichotomy between law and politics (Kelsen, 1943, 1945). Subsequently, he

3 acknowledged the legal-political nexus thus: 'It is a peculiarity of the law that it regulated its own creation and application. However, the creation and

5 application of the law are always determined not only by legal norms but also by non-legal, political norms, or, as it is usually formulated, by political 7 considerations' (Kelsen, 1957, p. 76).

A reasoned assessment is that in the late 1970s, Bobbio interrupted his

9 intellectual engagement with legal philosophy, and did not resume it again singularly. It is suggested that by pursuing political philosophy his legal

11 research potential was not fully realized. His writings, which previously traversed both law and politics, now focused on political thought, albeit

13 distinctly underpinned by legal reasoning. Two of his last contributions to law (Bobbio, 1988, 1996b) allude at a possible direction. In the first, he notes

15 the unproductiveness that can arise from slavishly adhering to 'backwardlooking analysis'. Law needs to be forward looking, but he refrains from

17 indicating a specific path, other than to accept the linkage between law and the overall social system. In the second, a probable path is implied: 'The

19 values of liberal democracy and the acknowledgement of human rights have helped to circumvent the gulf between natural law theories and legal

21 positivist theories' (Bobbio, 1996b, p. 121). More pointedly, he states that now "we live and work in a universe of shared values, which are those of

23 liberal democracy construed as a set of rules for living together. These rules are based on the acknowledgement of human rights and are aimed at

25 eliminating the use of force as a solution to social conflict' (ibid., p. 123). Here the individual, seen within the frame of a social contract, is paramount.

27 These comments suggest that Bobbio's conception of a general theory of law in the present context would be an amalgam of retrospective influences,

29 without some of the ambiguities, which would support his 'forward looking' rules of behaviour in liberal democracies and the resolution of conflicts without

31 violence. His posited extension of liberal democracy across the globe raises the importance of human rights and international law and the need for them to be

33 reflected in changes to traditional notions of sovereignty and citizenship.

Bobbio developed the legal-political nexus as a craftsman, and that, indeed,

35 is his original contribution. Richard Posner points out that 'craftsmanlike' is a high compliment in law (Posner, 1990, p. 28). Bobbio's distinctive use of the

37 legal-political nexus is illustrated by the following practices:

39 - the way he synthesizes relevant legal and political theories and applies them to particular debates and contexts; 
1 - the structure of his arguments, especially through linguistic analysis, and employment of neo-Enlightenment ideas;

3 - his role as a 'mediating intellectual' based on his juxtaposition of jurisprudential reasoning and political theorizing;

5 - his 'unfinished task' in law, subsequently expressed in his political philosophy and democratic theory;

7 - his fusion of Germanic legal culture and thought; the Continental influence of the Scandinavian school, Perelman and others; his empathetic

9 understanding of Anglo-American theorists; and committed interaction with his Italian contemporaries;

11 - his capacity to overcome the problem of 'categorization of knowledge', and to develop an open, reflexive mode of jurisprudential thought, which

13 is eclectic, multi-faceted and heuristic.

With regard to comparisons, it is interesting to note the similarity in Bobbio's philosophical writings with two early North American jurists, Learned Hand (1872-1961) and Benjamin Cardozo (1870-1938). For instance, when employing the metaphor of 'life as sparks from a fire', Bobbio (1984b, p. 187) wrote:

I have never looked upon life as a continuous whole, but rather as an aggregation of separate moments emerging from the opaque and impartial consistency of time ... like sparks that originate from the same burning log yet they are independent of each other, with each emanating its own brighter or fainter glimmering light.

Correspondingly, Learned Hand stated in his address to Yale law graduates:

Our selves are like flames, now dwindling to a spark, seen, but lightening nothing, now flaring to encompass all about, comprehending as much as we may choose to adopt as our own. (Hand, 1953, p. 89)

Remarkable similarities can also be found in their writings on democracy,

31 morals and politics, origins of the Constitution and political enthusiasm. Hand, for example, was a founding contributor to The New Republic in 1915,

33 and 'never swerved from his conviction that democracy was the system clearly preferable to any alternative' (Gunther, 1994, pp. 190-269, pp. 655,

35 781, note 85). Bobbio used the columns of La Stampa to engage in dialogue with the political class and promulgate his unswerving belief in democracy to

37 ordinary citizens.

There are also distinctive parallelisms with Cardozo's judicial philosophy

39 (Cardozo, 1924, 1928). For example, Patterson discusses Cardozo's writings on legal philosophy under the following headings: the sanction of law, law 
1 as a generalization, the opinion of the court as an expression of law, law as a prediction or as a norm, the judge as the centre of legal theory, the law as a 3 system and the status of natural law (Patterson, 1939a, pp. 71-91, 1939b, pp. 156-176). Besides Cardozo's judicial interpretations from the courts,

5 we find that his legal philosophy is grounded in Platonic and natural law traditions, with the latter being general rather than specific. Instead, his

7 specificity derives from his conception of the judicial function. Although Bobbio does not cite many judicial precedents from the courts, he draws

9 upon the contingent debates. Nevertheless, in the broader context of legal philosophy there is a similarity in their respective contributions, although in

11 different countries, to explicate their jurisprudential position. For example, Cardozo argues that there are four methods of judicial process:

The directive force of a principle may be exerted along the line of logical progression; this I will call the rule of analogy or the method of philosophy; along the line of historical development, this I will call the method of evolution; along the line of the customs of the community; this I will call the method of tradition; along the lines of justice, morals and social welfare, the mores of the day; and this I will call the method of sociology. (Cardozo, 1921, pp. 30-31)

Not dissimilarly, Bobbio's scientific and analytical method guides his legal philosophy. He describes its evolution, particularly up to the emergence of his promotional function of law; he is conscious of the importance of customs and habits, and places distributive justice and equality at the basis of a just society (Bobbio, 1987a, p. 103, 1996d, pp. 60-71). In terms of antecedents and comparison, Posner points out, basing his observation on Dworkin (1986) that in the merger of natural and positive law ... Cardozo is a precursor of Ronald Dworkin' (Posner, 1990, p. 29). On such a merger, Bobbio observation might be that:

It depends on the point of view one takes in judging it. It can happen that an author can be a positivist from a certain point of view, and an advocate of natural law from another. To illustrate, I provide the example of my personal case: in the face of the clash of ideologies, where no prevarication is possible, I am a natural law supporter. As far as the theory of law is concerned, I consider myself neither a natural law supporter nor a positivist. (Bobbio, 1962, p. 15)

Clearly, these legal philosophers share a deep interest in the importance of legal science and philosophy.

37 In essence, Bobbio is a reflexive legal philosopher. While his work does not have the form of an explicit and complete system of legal theory, it

39 is a revealing example of an 'open system'. This is exposed to continual verification of his acquired solutions, as well as those of others, and receptive 
1 to the changes in legal reality and in social and political knowledge. As a legal philosopher and intellectual of the left, Bobbio provides certain

3 indications towards minimizing the traditional anxiety about the supremacy of parliament, the basis for a 'good working democracy', and the fear of

5 the left that reactionary judges would use a written constitution to obstruct necessary social reform. As a neo-Kantian, Bobbio envisioned a world where

7 cosmopolitical rights are actively generated and protected throughout an increasingly democratized international community, with a higher tribunal,

9 or a 'Third party super partes', to settle conflicts without bloodshed. Bobbio's theories therefore constitute a fulcrum of understanding that can guide

11 modern social and political analysis. His comparisons with Anglo-American legal philosophers also highlight the way in which legal reasoning exerted

13 considerable influence on the way such authors contributed to political debate.

\section{CONCLUSION}

19 Bobbio's contribution to law is well recognized in the Italian and European contexts, and Latin America, but less so in the United States. He advanced

21 the understanding of law as legal science, or jurisprudence, and on the interconnection of legal and political philosophy. By the late 1970s, he

23 refined his theory of the legal system, on which he wrote in 1960, in fact, before Hart. For Bobbio, law consists of rules which both define and

25 distinguish a legal system from any other normative phenomena, such as morals and customs. Rules are legal because they belong to a legal system,

27 and a system is legal because of its specific characteristics as a system. This system comprises different types of legal rules, such as constitutive, power-

29 conferring rules and others. He reformulated the task of the general theory of law by extending it from the strictly formal knowledge, inherent in the

31 normative-linguistic structure of the legal system, to a specific sociological and political knowledge of the bases and social outcomes of this system.

33 During the early 1980s with the growth of the Welfare State, Bobbio promoted greater awareness of an incentivizing, or promotional, function

35 of law. This was mainly implemented through the technique of positive sanctions, and by comparing how the validity of legal norms occurs in the

37 legal system theorized by Kelsen and Hart. Ruiz concludes that 'This is what Bobbio presupposes when he speaks of the promotional function of law:

39 that norms with a positive sanction ... can be part of the legal system' (Ruiz, 1989, p. 195). 
1 Bobbio acknowledged the non-ideological and objective definition of the foundation of science in the justification of his political orientation 3 (theoretical and actual). In his view, the search for a state with the rule of law, peace and human rights protection can be linked to the rigorous method

5 of analytical legal theory. He strove to explicate the possible ways in which freedom and justice, individualism and pluralism, liberalism and democracy

7 can work together, instead of remaining hostile to one another. His theoretical detachment, intellectual rigour and persistent doubt, combined with his

9 political moderatism and dialogic engagement, were critical in his approach to the study of law. His body of legal, political and moral writings can be

11 considered an invaluable hermeneutic lens to address the challenges of a cosmopolitical world.

UNCITED REFERENCE

Kant (1907).

\section{NOTES}

1. Popper, K. (1962). Julius Kraft, 1898-1960. Ratio (IV June), 2. This memorial issue was dedicated to its founder, Julius Kraft.

2. The program of activities for the Bobbio Birth Centenary was planned to

25 unfold over3 years, as detailed in Italian, English and Spanish on the Web site. The International Congress titled 'From the 20th to the 21st Century: The Future of

27 Norberto Bobbio' was held in Turin on 15-17 October 2009. The Italian President, Giorgio Napolitano, delivered the inaugural address. The various thematic sessions considered were Bobbio's Ideals, Law in the decline of the state, The future of politics and Norberto Bobbio's influence on contemporary culture. The English version of the Web site was translated by the author, a member of the Birth

31 Centenary Committee, and was involved in the Centenary activities from midSeptember 2009 to mid-January 2010. The Web site contents include Bobbio's profile, a chronology of his main writings, a list of his prizes and awards, a number of interpretative essays on his figure and media articles. The Centenary celebrations concluded in October 2010 with a seminar, a theatre play and a public lecture that 35 drew on Bobbio's In Praise of Meekness (2000).

3. For Popper, see Bobbio (1946); for Schmitt, see Bobbio (1939, 1995b). See also Ross (1958, 1968), and Kelsen and Hart references.

4. Bobbio's professional and personal bibliographies are accessible at www .erasmo.it/gobetti/eng/default2.asp

5. Bobbio was arrested on 15 May 1935 (later released with a caution), together with other members of the 'Justice and Freedom' Group: Pavese, Mila, V. Foa, 
1 G. Einaudi and Antonicelli. On 6 December 1943, he was arrested again for clandestine activities in Padua and imprisoned in the Scalzi di Verona until the end of February 1944.

6. The seven public lectures on ethics and politics were presented by Michael Walzer, Umberto Eco, Giovanni Sartori, Stefano Rodotà, Gustavo Zagrebeslky,

5 Enzo Bianchi and Giuliano Pontara.

7. The matter (premise) and form (conclusion) difference in Kant, alluded to by Bobbio, is §IV Theorem III, Critique of Practical Reason.

8. Meaning a function that seeks to promote a particular conduct by conferring a benefit, and is also understood as a 'positive sanction'.

9. Julius Hermann von Kirchmann (1802-1884), Prussian philosopher and sociologist who rejected Hegel's dialectic, accepted Kant's critique of knowledge

11 and was receptive to positivism. In later years, he became quite interested in Comte and sought to introduce sociology as a systematic science in Germany. His position was close to the modern sociological school of jurisprudence. He held that morality is

13 a personal not a public matter, and political science is only concerned with determining the reasonableness of government.

15 10. Rudolf von Jhering (1818-1892) has been described as 'the most encyclopedic mind in German law in the 19th century'. In his Der Zweck im Recht, the so-termed lower levers that motivate human behaviours in society are identified in recompense and coercion. In turn, coercion is considered mechanical and psychological, but is also propulsive and compulsive. His two best-known jurisprudential books are The

19 Struggle for Law (von Jhering, 1997) and Law as a Means to an End (von Jhering, 1968). The bulk of Jhering's writings are in Roman and German law, and

21 jurisprudence, with the latter being quite influenced by the English Utilitarians and classical economic thought.

11. Talcott Parsons (1902-1979) sought to combine human agency and structure in one theory of societal community.

12. The 1974 Eighth World Congress of Sociology held in Toronto.

25 13. Bobbio borrows this term from Léon Duguit (1859-1928), French jurist and political theorist, noted for his application of philosophical positivism to jurisprudence and political theory. He aimed to develop a theory of law and the state based solely on experimental data and excluding all metaphysical ideas.

\section{REFERENCES}

Alchourrón-Bulygin, C. E., \& Bulygin, E. (1981). The expressive conception of norms. In: R. Hilpinen (Ed.), New studies in deontic logic (pp. 95-124). Dordrecht: Reidel Publishing.

Bellamy, R., Ferrajoli, L., Negri, T., \& Zolo, D. (2004). The legacy of Norberto Bobbio: Assessments and recollections. Critical Review of International Social and Political Philosophy, 7(3), 67-83.

39 Bobbio, N. (1938). L'analogia nella logica del diritto [Analogy in legal logic]. Torino: Istituto giuridico della R. Università. 
1 Bobbio, N. (1939). Book review: Carl Schmitt Der Leviathan in der Staatslehre des Thomas Hobbes. Hanseatische Verlagsanstalt, Hamburg, 1938. Rivista di Filosofia, 30(3), 283-284.

3

Bobbio, N. (1945). Stato e democrazia [The state and democracy]. Lo Stato Moderno, August, $159-160$.

5

Bobbio, N. (1946). Società chiusa e società aperta. Il Ponte, 2(2), 1039-1046.

Bobbio, N. (1950). Scienza del diritto e analisi del linguaggio [Legal science and linguistic

Bobbio, N. (1956). Liberalism old and new. Confluence, Centennial Issue, 239-251.

Bobbio, N. (1959). Trends in Italian legal theory. The American Journal of Comparative Law, 8 , 329-340.

Bobbio, N. (1962). Giusnaturalismo e positivismo giuridico [The theory of natural law and legal

11 positivism]. Rivista di Diritto Civile, 8(6), 3-15.

Bobbio, N. (1963a). Eguaglianza e dignità degli uomini [Equality and human dignity]. In:

13 AA.VV. [various authors], Diritti dell'uomo e nazioni unite (pp. 27-42). Padova: Cedam.

Bobbio, N. (1963b). Hans Kelsen. Novissimo Digesto Italiano, 11, 402-404.

Bobbio, N. (1964). Hans Kelsen. Rivista di filosofia, 55, 357-358.

15 Bobbio, N. (1965a). Giusnaturalismo e positivismo giuridico. Milan: Edizioni di Comunità.

Bobbio, N. (1965b). Diritto e guerra [Law and war]. Discorso all'inaugurazione dell'anno accademico 1964-65 (pp. 333-350). Torino: Accademia delle Scienze.

Bobbio, N. (1968). Ancora sulle norme primarie e norme secondarie [Still on primary and secondary rules]. Rivista di Filosofia, LIX(1), 35-53.

Bobbio, N. (1969). The promotion of action in the modern state. In: G. Hughes (Ed.), Reason, law and justice. Essays in legal philosophy (pp. 189-206). New York: University Press.

21 Bobbio, N. (1970). Studi per una teoria generale del diritto [Studies for a general theory of law]. Torino: Giappichelli.

Bobbio, N. (1971). Dell'uso delle grandi dicotomie nella teoria del diritto [On the use of the great dichotomies in legal theory]. Studi in onore di Giuseppe Grosso (Vol. 4, pp. 615-635). Torino: Giappichelli.

25 Bobbio, N. (1973). Hans Kelsen. Rivista internazionale di filosofia del diritto, 3, 425-429.

Bobbio, N. (1974). Teoria sociologica e teoria generale del diritto [Sociological theory and general theory of law]. Sociologia del Diritto, 1, 9-15.

Bobbio, N. (1975). Intorno all'analisi funzionale del diritto [Towards a functional analysis of law]. Sociologia del Diritto, 1, 1-25.

Bobbio, N. (1977). Dalla struttura alla funzione. Nuovi studi di teoria del diritto [From structure to function. New studies in legal theory]. Milano: Edizioni di Comunità.

31 Bobbio, N. (1981). Le ideologie e il potere in crisi [Ideologies and state power in crisis]. Le Monnier: Florence.

33 Bobbio, N. (1984a). La funzione promozionale del diritto rivisitata [The promotional function of law revisited]. Sociologia del diritto, 3, 7-27.

Bobbio, N. (1984b). Maestri e compagni. Firenze: Passigli.

35 Bobbio, N. (1987a). The future of democracy. Cambridge: Polity Press.

Bobbio, N. (1987b). La democrazia dei moderni paragonata a quella degli antichi (e a quella dei posteri). Teoria politica, 3(3), 3-17.

Bobbio, N. (1987c). A quarant'anni dalla Costituzione [The Constitution forty years later]. Nuova Antologia, January-March, 59-65. 
1 Bobbio, N. (1989). Pace [Peace]. Enciclopedia del Novecento. Istituto della Enciclopedia Italiana, $8,812-824$.

Bobbio, N. (1990a). Liberalism and democracy. London: Verso.

Bobbio, N. (1990b). Democrazia e segreto. In: P. Fois (Ed.), Il Trattato Segreto. Profili storicodiplomatici e regime giuridico (pp. 16-31). Padova: Cedam.

5 Bobbio, N. (1990c). Democracy - The threatened Utopia: An interview with Norberto Bobbio. P. Glotz \& O. Kallscheuer. Telos, 82, 134-143.

7 Bobbio, N. (1990d). Ricapitolazione della mia vita. In: P. Lacaita (Ed.), Cultura laica e impegno civile. Maestri e discepoli (pp. 681-700). Manduria: Lacaita.

Bobbio, N. (1992). Diritto e potere. Saggi su Kelsen [Law \& power. Essays on Kelsen]. Napoli: Edizioni Scientifiche Italiane.

Bobbio, N. (1993a). Thomas Hobbes and the natural law tradition (D. Gobetti, Trans.). Chicago:

11 University of Chicago Press.

Bobbio, N. (1993b). Teoria generale del diritto [A general theory of law]. Torino: Giappichelli.

Bobbio, N. (1995a). Democracy and the international system. In: D. Archibugi \& D. Held (Eds), Cosmopolitan democracy. An agenda for a new world order (pp. 17-41). Cambridge: Polity.

15 Bobbio, N. (1995b). Carl Schmitt, Norberto Bobbio. Diritto e Cultura [Law \& culture], JanuaryJune, 1, 49-80.

17 Bobbio, N. (1995c). L'utopia capovolta [The upturned utopia]. La Stampa: Turin.

Bobbio, N. (1996a). The age of rights. Cambridge: Polity.

Bobbio, N. (1996b). An autobiographical Aperçu of legal philosophy. Ratio Juris, 9(2), $121-124$.

Bobbio, N. (1996c). Democrazia e pace: La calamita di una vita di studi [Democracy and peace: The magnet of a lifetime of research]. La Stampa, 7 June.

Bobbio, N. (1996d). Left and right. The significance of a political distinction. Cambridge: Polity Press.

Bobbio, N. (1997). Verso la Seconda Repubblica [Towards the Second Republic]. La Stampa: Turin.

25 Bobbio, N. (1998). Kelsen and legal power. In: S. L. Paulson \& B. L. Paulson (Eds), Normativity and norms. Critical perspectives on Kelsenian themes (pp. 435-449). Oxford:

27 Clarendon.

Bobbio, N. (2000). In praise of meekness. Cambridge: Polity.

Bobbio, N. (2001). Old age and other essays. Cambridge: Polity.

Bobbio, N. (2002). A political life. Cambridge: Polity.

Bobbio, N. (2004). Ultime volontà (My final wishes). La Stampa, 10 January.

31 Bobbio, N. (2006). Lezioni Norberto Bobbio. Sette interventi su etica e politica [Seven public lectures on ethics and politics]. Torino: Einaudi.

33 Bobbio, N., \& Zolo, D. (1998). Hans Kelsen. The theory of law and the international legal system. A talk. European Journal of International Law, 9, 355-367.

Cardozo, B. (1921). The nature of the judicial process. New Haven, CT: Yale University Press.

35 Cardozo, B. (1924). The growth of the law. New Haven, CT: Yale University Press.

Cardozo, B. (1928). The paradoxes of legal science. Westport, CT: Greenwood Press.

37 Chataway, T. (2001). Where does the dove of peace fly?. Convivio, 7, 136.

Chataway, T. (forthcoming). Cosmopolitical citizenship for a multi-level world. Griffith Law Review - Law Theory Society, 19(3).

39 Davidson, A. (2004). Norberto Bobbio 18/10/1909-9/1/2004. Thesis Eleven, 78, 4-7. 
1 Dworkin, R. (1986). Law's empire. London: Fontana.

Falk, R., \& Shuman, S. (1962). The Bellagio conference on legal positivism. Journal of Legal Education, 14, 213-228.

Ferrari, V. (2004). The firm subtleties of a philosopher in 'Everlasting Doubt': Remembering Norberto Bobbio. Journal of Law and Society, 31(4), 578-591.

5 Gunther, G. (1994). Learned hand. The man and the judge. New York: Knopf.

Hand, L. (1953). The spirit of liberty. New York: Knopf.

7 Hart, H. L. A. (1961). The concept of law. Oxford: Oxford University Press.

Hohfeld, W. N. (1913-1914). Fundamental legal conceptions. Yale Law Journal, 23, 16-59.

Jori, M. (2004). Ci ha insegnato la differenza tra legge e morale [He taught us the difference between law and morals]. Il Sole-24 Ore, 10 January.

Kant, I. (1907 [1781]). Critique of pure reason (M. Müller, Trans.). New York: Macmillan.

11 Kelsen, H. (1942). Discussion of post-war problems. American Academy of Arts and Sciences, $75,13$.

13 Kelsen, H. (1943). Society and nature. A sociological inquiry. Chicago: University of Chicago Press.

Kelsen, H. (1945). General theory of law and state (A. Wedberg, Trans.). New York: Russell \& Russell.

Kelsen, H. (1952). Principles of international law. New York: Rinehart \& Company.

17 Kelsen, H. (1957). Collective security under international law. International Law Studies. Naval War College. Washington: Government Printing Office.

Kelsen, H. (1973 [1933]). State-form and world outlook. In: O. Weinberger (Ed.), Essays in legal and moral philosophy (pp. 95-113). P. Heath (Trans.). Boston: Reidel.

Kelsen, H. (1992). Introduction to the problems of legal theory. Oxford: Clarendon Press.

21 Krader, L. (1966). Anthropology and early law. New York: Basic Books.

Kramer, M. H., Grant, C., Colburn, B., \& Hatzistavrou, A. (Eds). (2008). The legacy of H.L.A. Hart. Legal, political and moral philosophy. Oxford: Oxford University Press.

Patterson, E. W. (1939a). Cardozo's philosophy of law. University of Pennsylvania Law Review, November Part I, 71-91.

25 Patterson, E. W. (1939b). Cardozo's philosophy of law. University of Pennsylvania Law Review, December Part II, 156-176.

27 Posner, R. A. (1990). Cardozo. A study in reputation. Chicago: The University of Chicago Press.

Raz, J. (1976). Critical study: Kelsen's general theory of norms. Philosophia, 6, 495-504.

Raz, J. (1990). Practical reason and norms. Princeton, NJ: Princeton University Press.

Ross, A. (1958). On law and justice. London: Stevens and Sons.

Ross, A. (1968). Directives and norms. London: Routledge \& Kegan Paul.

31 Ruiz, S. G. (1989). Semiotic codes and deontic operators. Consequences of Norberto Bobbio's promotional function of law. International Journal for the Semiotics of Law, 2(5), 183-198.

von Jhering, R. (1968 [1877-1882]). Law as a means to an end. New York: A.M. Kelley.

von Jhering, R. (1997 [1872]). The struggle for law (J. Lalor, Trans.). New York: Lawbook Exchange. 


\section{AUTHOR QUERY FORM}

\begin{tabular}{|l|l|l|}
\hline & Book: SLPS-V055-3610310 & \multicolumn{1}{c|}{$\begin{array}{c}\text { Please e-mail or fax your responses } \\
\text { and any corrections to: }\end{array}$} \\
Chapter: 6 & $\begin{array}{l}\text { E-mail: } \\
\text { Fax: }\end{array}$ \\
\hline
\end{tabular}

Dear Author,

During the preparation of your manuscript for typesetting, some questions may have arisen. These are listed below. Please check your typeset proof carefully and mark any corrections in the margin of the proof or compile them as a separate list.

\section{Disk use}

Sometimes we are unable to process the electronic file of your article and/or artwork. If this is the case, we have proceeded by:

Scanning (parts of) your article $\square$ Rekeying (parts of) your article

Scanning the artwork

\section{Bibliography}

If discrepancies were noted between the literature list and the text references, the following may apply:

The references listed below were noted in the text but appear to be missing from your literature list. Please complete the list or remove the references from the text.

UNCITED REFERENCES: This section comprises references that occur in the reference list but not in the body of the text. Please position each reference in the text or delete it. Any reference not dealt with will be retained in this section.

Queries and/or remarks

\begin{tabular}{|l|l|l|}
\hline $\begin{array}{l}\text { Location in } \\
\text { Article }\end{array}$ & \multicolumn{1}{|c|}{ Query / remark } & Response \\
\hline AU:1 & $\begin{array}{l}\text { As per the style, please provide } \\
\text { the Abstract. }\end{array}$ & \\
\hline AU:2 & $\begin{array}{l}\text { Please check the insertion of } \\
\text { book names "The Struggle for } \\
\text { Law" and "Law as a Means to an } \\
\text { End" in note 10. }\end{array}$ & \\
\hline AU:3 & $\begin{array}{l}\text { Please provide the vol. no. in the } \\
\text { refs. Bobbio (1950, 1956). }\end{array}$ & \\
\hline AU:4 & $\begin{array}{l}\text { Please provide the year and page } \\
\text { range in the ref. Chataway } \\
\text { (forthcoming). }\end{array}$ & \\
\hline
\end{tabular}

